\title{
Costochondral Joint 7
}

National Cancer Institute

\section{Source}

National Cancer Institute. Costochondral Joint 7. NCI Thesaurus. Code C102289.

The seventh hyaline cartilag inous joint between the ribs and costal cartilage. 